\title{
世帯の空間分布予測モデルを用いた土地利用計画支援システムの開発 DEVELOPMENT OF A LAND USE PLANNING SUPPORT SYSTEM USING HOUSEHOLD DISTRIBUTION PREDICTION MODEL
}

\author{
長 崎 浩 紀*, 渡辺 公次郎**, 近藤 光 男 ***
}

Hiroki NAGASAKI, Kojiro WATANABE and Akio KONDO

\begin{abstract}
In this paper, we developed a land use planning support system using the household distribution prediction model. The concept of multi-agent systems was used in the model. The agent of this model is a household. The agent decides decision of migration depending on its own conditions and migration potential at current address. Next, the agent starts to select the next address by land potential. If land potential of the next address is higher than the current address, the agent will migrate to the selected address. This model was incorporated in GIS to develop a land use planning support system.
\end{abstract}

Keywords: Land Use Planning, Planning Support Systems, Geographic Information Systems, Household Distribution, Multi-Agent Systems 土地利用計画、計画支援システム、地理情報システム、世帯分布、マルチェージェントシステム

\section{1. はじめに}

\section{1 背景と目的}

現在、徳島都市圈を始めとする多くの地方都市では、郊外化と中 心市街地衰退化が同時に進行しており、様々な弊害をもたらしてい る。分散的な郊外化は、緑地や農地の減少、交通量の増加、非効率 的な社会資本整備などを引き起こし、中心市街地衰退化の大きな原 因にもなっていることから、今後は、郊外部の開発規制と中心市街 地活性化の両方に配慮した土地利用計画が必要である。その策定の ためには、土地利用規制、誘導の効果を様々な形で予測、評価し、 分かりやすく表示させることで、プランナーの意思決定を支援する システムが必要である。

そこで本研究では、マルチェージェントシステム(MAS)を用いて 個々の世帯の移動行動をモデル化し、そのモデルをGISソフトに組み 込むことで、土地利用規制の効果を、世帯の空間分布で予測するこ とが可能な土地利用計画支援システム(LUPS)を開発することを目的 とする。

\section{2 研究対象地域}

研究対象地域は、徳島市、鳴門市、小松島市、松茂町、北島町、 藍住町、石井町から構成される徳島都市圈とする。対象地域の位置
を図1、人口と世帯数を表1に示す。この地域は、徳島県の政治、経 済、文化の中心地域であり、県全体の $58 \%$ の人口が集積する。中心 都市である徳島市では、特に中心市街地で人口減少が進んでいるも のの、藍住町や松茂町など郊外部では人口が増加しており、それに 伴い都市機能の郊外化も進んでいる。また、交通渋滞も慢性化して いることから、より実効性のある土地利用計画が求められている。

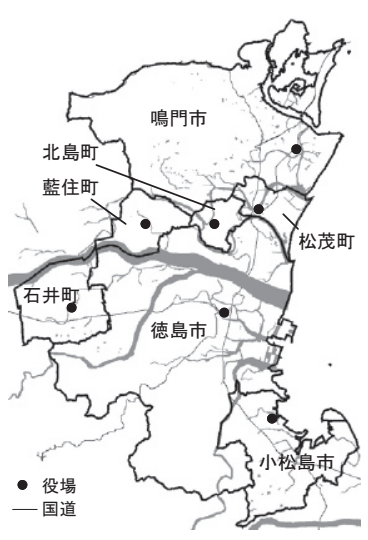

図1 徳島都市圈
表1 徳島都市圈の人口と世帯数

\begin{tabular}{|c|c|c|c|c|c|}
\hline \multirow{2}{*}{ No } & \multirow{2}{*}{ 市町名 } & \multirow{2}{*}{$\begin{array}{c}\text { 面積 } \\
{\left[\mathrm{km}^{2}\right]}\end{array}$} & \multicolumn{3}{|c|}{ 人口[人] } \\
\hline & & & 1980 & 1990 & 2000 \\
\hline 1 & 徳島市 & 191.39 & 249,343 & 263,356 & 268,218 \\
\hline 2 & 鳴門市 & 135.46 & 63,423 & 64,575 & 64,620 \\
\hline 3 & 小松島市 & 45.11 & 43,636 & 43,188 & 43,078 \\
\hline 4 & 石井町 & 28.83 & 24,434 & 25,207 & 26,02 \\
\hline 5 & 松茂町 & 13.1 & 10,196 & 12,096 & 14,2 \\
\hline 6 & 北島町 & 8.77 & 16,466 & 18,986 & 19,8 \\
\hline 7 & 藍住町 & 16.27 & 19,713 & 25,674 & 30,36 \\
\hline \multicolumn{2}{|r|}{ 計 } & 438.93 & 427,211 & 453,082 & 466, \\
\hline \multirow{2}{*}{ No } & \multirow{2}{*}{ 市町名 } & \multirow{2}{*}{$\begin{array}{c}\text { 面積 } \\
{\left[\mathrm{km}^{2}\right]}\end{array}$} & \multicolumn{3}{|c|}{ 世帯数[世帯 } \\
\hline & & & 1980 & 1990 & 2000 \\
\hline 1 & 德島市 & 191.39 & 79,754 & 90,738 & 104,89 \\
\hline 2 & 鳴門市 & 135.46 & 17,691 & 19,052 & 21,841 \\
\hline 3 & 小松島市 & 45.11 & 12,439 & 12,983 & 14,742 \\
\hline 4 & 石井町 & 28.83 & 6,358 & 6,944 & 80 \\
\hline 5 & 松茂町 & 13.1 & 001 & 3,524 & 4,8 \\
\hline 6 & 北島町 & 8.77 & 4,918 & 5,968 & $6,8 \varepsilon$ \\
\hline 7 & 藍住町 & 16.27 & 5,264 & 7,351 & 9,9 \\
\hline & 計 & 438.93 & 129,025 & 146,560 & 171,19 \\
\hline
\end{tabular}

* 中央コンサルタンツ(㑣) 修士 (工学)

** 徳島大学大学院ソシオテクノサイエンス研究部 助教・博士 (工学)

*** 徳島大学大学院ソシオテクノサイエンス研究部 教授・工博
Chuoh Consultants Co., Ltd., M. Eng.

Assistant Prof., Institute of Technology and Science, The Univ. of Tokushima, Dr. Eng.

Prof., Institute of Technology and Science, The Univ. of Tokushima, Dr. Eng. 


\section{3 既往研究}

ここでは、関連する既往研究を挙げ、本研究との違いを述べる。 まず、MASを用いた都市モデルとして、奥 ${ }^{1), 2), 3}$ は一連の研究の中 で、土地利用分布を自己組織化の原理に基づき説明することを目的 に、セルオートマトン（CA）の考え方による土地利用変化モデルを 開発している。Kii and $\mathrm{Doi}^{4}$ は、コンパクトシティの効果を把握する ことを目的とした、MASを用いた土地利用交通モデルを開発してい る。池谷ら ${ }^{5)}$ は、MASを用いて人口分布の動的特性をモデル化してい る。安藤ら ${ }^{6}$ は、都市の衰退過程をMASによりモデル化し、人口、空 き家、地代、商業地の変化が都市の衰退化にどう影響するかを検討 している。以上のように、奥 ${ }^{1,2), 3)}$ のデルは土地利用の変化を、Kii

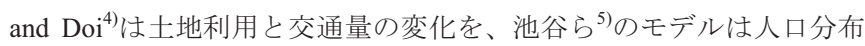
を、安藤ら ${ }^{6}$ のモデルは人口、空き家、地代、商業地の変化を予測し ている。本研究では、世帯の移動行動をMASによりモデル化し、3次 メッシュ (約 $1 \mathrm{~km} \times 1 \mathrm{~km})$ 単位で予測しており、この点が既往研究と は異なる。

次に、土地利用計画支援システムに関する研究では、吳ら゙は、用 途地域指定を支援するため、作業過程をシステム化することでエキ スパートシステムを開発している。大貝ら ${ }^{8)}$ は、環境管理計画立案支 援エキスパートシステムとGISを統合し、環境に配慮した土地利用計 画の現況把握から計画立案までを支援する計画支援システムを開発 している。長崎ら ${ }^{9}$ は、途上国における土地利用計画策定支援を目的 とした、計画支援システムを開発している。これは、GISに、CAを 用いた市街化予測モデルとAHP（階層分析法）を用いた土地利用計 画図作成支援システムを統合したシステムである。金ら ${ }^{10)}$ は、福岡 市と川崎市を対象に、マクロデータを用いた土地利用の遷移行列を 分析することで遷移の特徵、定常状態の土地利用構成の特徵を明ら かにし、その結果から、将来の土地利用フレームが設定された場合 の土地利用遷移行列を推定し、土地利用変化の予測を行っている。 これらの研究との相違点は、GISに世帯の空間分布予測モデルを組み 込むことで、GIS上で様々な土地利用計画案が実施された場合の世帯 分布を予測し、案の検討が行える支援システム、という点である。

\section{4 本論文の構成}

第2章では、世帯の空間分布予測モデル（HDPM）を開発し、第3 章ではそのモデルをGISソフトに組み込むことでLUPSを開発する。 第4章では、対象地域に開発したシステムを適用し、シナリオ別の将 来予測を行う。最後に第 5 章で成果と今後の課題を述べる。

\section{2. 世帯の空間分布予測モデルの開発}

\section{1 モデルの考え方}

MASとは、多数の自律した主体が相互に依存、協調することで、 全体として様々な現象を捉えることが可能なシステムである。世帯 の社会移動は、各世帯の家族構成、収入、居住環境に関する意識と いった世帯属性や、場所の利便性や安全性など周辺環境の違いによ り変化すると考えられる。ここでは、ある世帯の移動は他の世帯や 周辺環境との相互作用により決定されると考え、MASを使ってモデ ル化する。本モデルにおけるエージェントは、世帯（世帯主）、地 価、土地利用とし、互いに相互作用を及ぼし合いながら、世帯の空 間分布、世帯の属性、地価、土地利用比率が変化する。詳細は2.6に
表2 用いたデータ

\begin{tabular}{|l|l|}
\hline 項目 & 内容 \\
\hline 道路網 & 国道 \\
\hline 施設位置 & $\begin{array}{l}\text { 駅、医療施設、小中学校、交番·警察署、県庁、公民館·集会所、商業 } \\
\text { 施設 }\end{array}$ \\
\hline 土地利用 & 市街地、空地、農地、森林、水域 \\
\hline 土地利用規制 & $\begin{array}{l}\text { 市街化区域(住居系、商業系、工業系、その他)、市街化調整区域、未 } \\
\text { 線引き都市計画区域、都市計画区域外 }\end{array}$ \\
\hline 地形 & 標高 \\
\hline その他 & $\begin{array}{l}\text { 世帯数、地価、大規模住宅団地、DID、犯罪発生率、事故発生率、火 } \\
\text { 災発生率 }\end{array}$ \\
\hline
\end{tabular}

示す。

\section{2 データ整備}

本モデルで用いるデータを表2に示す。本モデルでは、世帯の空間 分布を3次メッシュ（約 $1 \mathrm{~km} \times 1 \mathrm{~km} ）$ 単位で予測する。メッシュサイ ズは小さいほど詳細な分布を捉えることができるが、ここでは、世 帯数データに国勢調查の地域メッシュ統計を用いたため、3次メッ シュとした。土地利用は、国土数值情報の土地利用細分メッシュ データを市街地、空地、農地、森林、水域に再分類して用いた。区 域区分と用途地域は、都市計画総括図と用途地域変更総括図を用い て作成した。駅、医療施設、小中学校、交番・警察署、県庁、国道 の位置は、数值地図25000（空間デー夕基盤）を基に、公民館・集会 所は一覧表から位置をデータ化した。商業施設は、床面積 $1,000 \mathrm{~m}^{2}$ 以 上の大規模小売店舗と、徳島県内でチェーン展開しているスーパー マーケット $\left(1,000 \mathrm{~m}^{2}\right.$ 未満も含む) の位置をデータ化した。これらの 商業施設は世帯移動に関係すると考えたためである。地価は、国土 数值情報の地価公示点（公示地価）、都道府県地価調查点（基準地 価）データを用いる。ただし、両者が重複している地点について は、公示地価の方を用いる。大規模住宅団地はその位置を、人口集 中地区（DID）は、総務省統計局が公開しているDID境界図を用いて

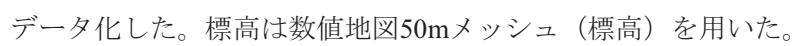

これらのデータを用いて、3次メッシュごとに世帯数、各施設から の距離、土地利用・ ・域区分・用途地域・大規模住宅団地の各面積 比率、平均標高、DIDが $50 \%$ 以上含まれているかどうか、地価を属性 として付加した。データの制約上、公示地価、基準地価が存在しな い3次メッシュについては、存在するメッシュのデータを用いて重回 帰分析を行い、得られた式より地価を推計した。

\section{3 世帯の行動}

世帯は、各自の属性と現在住んでいる土地の魅力度より、そこか ら移動する（引越す）かどうかを決める。移動先は、現在より魅力 度が高い場所とし、対象地域内にそういった場所がなければ空間 外、寸なわち徳島都市圈外一移動する。

まず、メッシュJに居住する世帯iは、移動の意思を次式に示す移動 ポテンシャル $P_{i j}$ にり決定する。

$P_{i J}=P_{i}^{a} \cdot P_{i}^{r} \cdot P_{i}^{y} \cdot$ Land $_{i J}$

ここで、 $P^{a}{ }_{i} 、 P^{r}{ }_{i} 、 P_{i}^{y}{ }_{i}$ はそれぞれ $i の$ 年齢、年収、居住年数に対する移

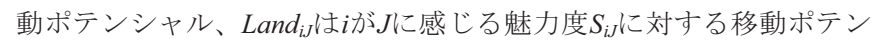
シャルである。移動ポテンシャルに、年齢、年収、居住年数を用い た理由であるが、年齢は、就職や進学、結婚などにより転居する可 能性を考慮するため、年収は、収入の違いが住宅の購入や転居する 
場所の決定に影響を及ぼすと考えたため、居住年数については、転 勤など定期的に転居が必要な世帯を考慮するために用いた。 Land $d_{i j}$ は、魅力度が低いほど移動の意思が強くなると考え、式(2)に示寸指 数関数型とした。

Land $_{i J}=\exp \left(-\omega \cdot S_{i J}\right)$

ここで、孫数である。

本モデルでは、世帯が移動する可能性が大きいほど $P_{i J}$ が高くなる よう、各要因の值を設定している。しかし、実際には $P_{i J}$ が大きい世 帯が必ず移動するとは限らない。現実の世帯の移動は、式(1)で用い た要因以外にポテンシャルとして設定しにくい不確定要素にも左右 されると考えられる。そこで、最小值 0 、最大值 1 の乱数值 $r$ (一様乱 数）を用いることで、 $P_{i j}$ が $r$ より大きければiは移動を決意し、移動 先の選定に移るようにした。これにより、 $P_{i J}$ が大きいほど、iは移動 を決意しやすくなるが、そうならない可能性も含ませることができ る。以上の方法で世帯移動の意思決定に不確定要素を加味させた。

次に、対象空間内のメッシュ $K$ をランダムに選択し、iが $K に$ 感じる 魅力度 $S_{i K}$ を算出する。この值が $S_{i J}$ よりも高い場合、 $i$ は $K$ に移動し、 低い場合は別のメッシュを選択する。この過程を繰り返すことで移 動先を決めるが、対象地域内のメッシュ数以上の回数だけ繰り返し ても $S_{i J}$ より魅力度の高いメッシュが存在しない場合、iは対象地域内 に魅力がないと判断し、対象地域外に移動する。なお、本モデルで は同一メッシュ内での移動は想定していない。また、対象空間内の メッシュには、上限世帯数を設定していない。その理由は、各メッ シュの上限世帯数は、戸建て、集合住宅といった住宅種別、規模、 その場所の容積率等に左右され、しかもそのメッシュに建設される 住宅種別は時間とともに変化することが考えられるため、3次メッ シュ単位ではうまく設定することができなかった。しかし、何の制 約もなければ魅力度の高いメッシュに世帯が集中してしまうため、 後述する世帯密度に関する魅力度を用いて過度の集中を抑制した。

\section{4 土地の魅力度}

土地の魅力度は、土地が持つ特性に加えて個人の状態や価值観に よっても大きく左右される。そこで、これらを考慮し土地の魅力度 $S_{i J}$ を次式で算出する。

$S_{i J}=\frac{\sum_{n=1}^{5} \alpha_{n} \cdot C_{J}^{n}}{5} \times \frac{\sum_{n=6}^{9} \alpha_{n} \cdot C_{J}^{n}}{4} \times \alpha_{10} \cdot C_{J}^{10} \times \frac{\sum_{n=11}^{16} \alpha_{n} \cdot C_{J}^{n}}{6} \times \alpha_{17}$

ここで、各変数の意味は表 3 に示寸とおりである。 $\alpha_{1} \sim \alpha_{16}$ は各魅力度 に重みを与える係数で、この設定により個人の価值観を反映させ る。詳細は後述する。 $\alpha_{17}$ は標高によって変化する係数であり、標高 が一定值以下の場合は 1.0 、それ以上は 0.5 とする。
次に、表3に示寸各変数の考え方を説明する。

「利便性」に関する魅力度は、生活する上で必要な施設からの距 離に応じて設定した。「安全性」に関する魅力度は、警察関連施設 からの距離と、犯罪・事故・火炎発生率に応じて設定した。「土地 利用規制」に関寸る魅力度は、区域区分と各種用途地域指定を取り 上げ、新規開発が行われやすいほど、また良好な居住環境が形成さ れやすいほど高くした。「その他」の指標として、税金に関する魅 力度は税率に応じて設定し、世帯密度に関する魅力度は、シミュ レーション開始時の密度との差が大きくなるほど低くした。周辺の 世帯年収と世帯主年齢に関する魅力度は、同程度の年収、世帯主年 齢の世帯が集まりやすいと考えたため、そういった場合に高くし た。大規模住宅団地に関する魅力度は、大規模住宅団地では住環境 に配慮した整備が行われていると考えられるため、団地の面積に応 じて設定した。土地利用に関する魅力度は、土地利用の違いが開発 のしやすさに影響を及ぼすことが考えられるため、市街地、農地、 空地別に魅力度を設定した。

以下に、各変数の設定方法の詳細を述べる。

利便性と安全性（警察関連施設密度）に関する魅力度 $C^{1} \sim C^{6}{ }_{J}$ は、 対象地域内の過去の移動世帯数と、各施設までの距離・警察関連施 設密度を集計し、両者を多項式近似させて求めた。以下に $C_{J}^{1}$ を求め る式を示す。

$C_{J}^{1}=\beta_{1} \cdot\left(\text { dist }_{J}^{1}\right)^{6}+\beta_{2} \cdot\left(\text { dist }_{J}^{1}\right)^{5}+\beta_{3} \cdot\left(\text { dist }_{J}^{1}\right)^{4}+\beta_{4} \cdot\left(\text { dist }_{J}^{1}\right)^{3}+$ $\beta_{5} \cdot\left(\text { dist }_{J}^{1}\right)^{2}+\beta_{6} \cdot\left(\right.$ dist $\left._{J}^{1}\right)+\beta_{0}$

ここで、 dist $^{1}{ }_{\text {は }}$ はメッシュJから幹線道路までの距離 $[\mathrm{km}] 、 \beta_{1} \sim \beta_{5}$ は係 数、 $\beta_{0}$ は定数項である。 $C^{2}{ }_{J} \sim C^{5}{ }_{J}$ は、 dist ${ }_{J}{ }_{J}$ を表 3 に示寸各施設からの 距離に変えて、警察関連施設密度に対する魅力度 $C^{6}{ }_{J}$ は、距離を密度 に変えて計算する。

安全性（犯罪・事故・火災発生率）に関寸る魅力度 $C^{7} \sim C^{9}{ }_{J}$ は、次 式に示寸指数関数型とした。

$C_{J}^{7 \sim 9}=\exp \left(-r_{i s k_{1 \sim 3}}\right)$

ここで、risk $k_{1}$ 単位人口当たりの犯罪発生率、risk 2 は事故発生率、 risk 3 は火災発生率である。

土地利用規制に関する魅力度 $C^{10}{ }_{J}$ は、次式で算出する。

$C_{J}^{10}=\sum_{n=1}^{7} \delta_{n} \cdot$ rate kubun $_{J}^{n}$

ここで、rate_kubun ${ }^{1 \sim 7} J$ は、順番に、Jの住居系用途地域、商業系用途 地域、工業系用途地域、その他の用途地域、調整区域、未線引き都 市計画区域、都市計画区域外の面積比率である。 $\delta_{1} \sim \delta_{7}$ は新規開発と 居住地環境形成に関する影響度で、次式で計算する。

表3 式(3)の各変数の意味

\begin{tabular}{|c|c|c|c|c|c|}
\hline 変数 & & 内容 & 変数 & & 内容 \\
\hline$C_{J}^{1}$ & \multirow{5}{*}{ 利便性 } & 幹線道路までの距離に対する魅力度 & $C_{J}^{10}$ & 規制 & メッシュJの土地利用規制に対する魅力度 \\
\hline$C_{J}^{2}$ & & 商業施設までの距離に対する魅力度 & $C_{J}^{11}$ & \multirow{6}{*}{ その他 } & メッシュ $J$ 税金に対する魅力度 \\
\hline$C_{J}^{3}$ & & 医療機関までの距離に対する魅力度 & $C_{J}^{12}$ & & メッシュJの世帯密度に対する魅力度 \\
\hline$C_{J}^{4}$ & & 小中学校までの距離に対する魅力度 & $C_{J}^{13}$ & & 周辺の世帯年収に対する魅力度 \\
\hline$C_{J}^{5}$ & & 公民館·集会所までの距離に対する魅力度 & $\mathrm{C}_{\mathrm{J}}^{14}$ & & 周辺の世帯主の年齢に対する魅力度 \\
\hline$C_{J}^{6}$ & \multirow{4}{*}{ 安全性 } & 交番·警察署の設置密度に対する魅力度 & $C_{J}^{15}$ & & メッシュJに存在する大規模住宅団地に対する魅力度 \\
\hline$C_{J}^{7}$ & & 犯罪発生率に対する魅力度 & $C_{J}^{16}$ & & メッシュJの土地利用に対する魅力度 \\
\hline$C_{J}^{8}$ & & 事故発生率に対する魅力度 & \multirow{2}{*}{\multicolumn{3}{|c|}{ 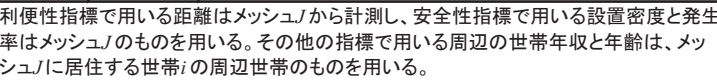 }} \\
\hline$C_{J}^{9}$ & & 火災発生率に対する魅力度 & & & \\
\hline
\end{tabular}


$\delta_{1 \sim 7}=\left(\varepsilon_{1 \sim 7}+\phi_{1 \sim 7}\right) / 2$

ここで、 $\varepsilon_{1} \sim \varepsilon_{7}$ はで指定されている土地利用規制が新規開発に、 $\varphi_{1} \sim$ $\varphi_{7}$ は居住地環境形成に及ぼす影響度である。 $\varepsilon$ と $\varphi$ の添字1 7は、式 (6)のrate_kubun ${ }^{1 \sim 7}{ }_{J}$ の添字1〜7と同じ土地利用規制を示している。

税金に関する魅力度 $C^{11}{ }_{J}$ は、Jに居住する $i$ の年収 Income $i$ に対する税 額Tax ${ }_{i J}$ で表す。 $C^{11}{ }_{J}$ を式(8)に、Tax ${ }_{i J}$ を式(9)に示す。

$C_{i, J}^{11}=\operatorname{Tax}_{i,} /$ Income $_{i}$

Tax $_{i J}=$ Price $_{J} \cdot$ site_area $_{i} \cdot \gamma_{1} \cdot$ taxrate $_{J}+$ Cost $\cdot$ build_area $a_{i} \cdot \gamma_{2} \cdot$ taxrate $_{J}$

ここで、Price $\left[\mathrm{m}^{2}\right] 、$ taxrate $_{J}$ はの税率、Costは単位面積当たりの建築工事費 $[$ 円/ $\left.\mathrm{m}^{2}\right]$ 、build_area $a_{i}$ は $i$ 持つ建物の延面積 $\left[\mathrm{m}^{2}\right] 、 \gamma_{1}$ と $\gamma_{2}$ は、課税標準額の 割引率である。Jが市街化区域内の場合、taxrate J固定資産税率と都 市計画税率の和、それ以外の場合は固定資産税率のみと寸る。

周辺世帯に関する魅力度 $C^{12}{ }_{J}$ は、次式で算出する。この魅力度は、 世帯の密度が居住環境に及ぼす影響を反映させるために用いた。具 体的には、シミュレーション開始時に比べて、周囲の世帯密度が上 昇もしくは下降するほじ、密集もしくは散在のため、居住環境が悪 化すると考えた。

$C_{J}^{12}=1-\left|a p p \_d e n_{J}-d e n_{J}\right| / a p p \_d e n_{J}$

ここで、denJはJの世帯密度、app_denJはJのシミュレーション開始時 の世帯密度である。ただし、den が $a p p \_d e n_{J}$ の2 倍以上である場合、 $C^{12}=0$ とする。

周辺世帯に関する魅力度 $C^{13}{ }_{J} 、 C^{14}{ }_{J}$ は、次式で算出する。

$C_{J}^{13}=$ equal_income ${ }_{i J} /$ total_agt $t_{J}$

$C_{J}^{14}=$ equal_age $e_{i J} /$ total_agt

ここで、equal_income $i_{i} 、$ equal_age $e_{i J}$ は、Jに居住する $i$ と同じ年収階 層、年齢階層の世帯数、total_agt (12)は、Jに居住する $i$ と同じ年収、年齢の世帯が集まることで、その 場所の魅力度が高くなる。これにより、世帯間の直接的な相互作用 を考慮する。

大規模住宅団地に関する魅力度 $C^{15}{ }_{\text {J }}$ は、次式で算出する。

$C_{J}^{15}=h e_{-}$area $_{J} /$ area $_{J}$

ここで、he_area 積である。

周辺土地利用に関する魅力度 $C^{16}{ }_{\text {J }}$ は、次式で算出する。

$C_{J}^{16}=\sum_{n=1}^{3} \eta_{n} \cdot$ rate landuse $_{J}^{n}$

ここで、rate_landuse ${ }_{J}^{1} \sim$ rate_landuse ${ }_{J}{ }_{J}$ は、Jの市街地、農地、空地比 率であり、 $\eta_{1} \sim \eta_{3}$ は係数である。

次に、式(3)の $\alpha_{1} \sim \alpha_{17}$ 、式(7)の $\varphi_{1} \sim \varphi_{7}$ の設定について説明する。

一般に、土地の魅力度は個人の価值観によっても左右されると考 えられる。そこで、世帯の居住志向パターン11)として、中心市街地 志向型（利便性重視、快適性・コミュニティ形成を軽視）、郊外部
志向型（快適性・コミュニティ形成を重視、利便性軽視）、コミュ ニティ重視型（コミュニティ形成を重視、利便性軽視）、経済性重 視型（経済性のみ重視し他は軽視）、無関心型（特定の要因に左右 されない）の5つを想定し、各パターンに応じて係数を変化させる。

\section{5 モデル内の時間と世帯の変化}

本モデルでは、空間内の移動世帯数と空間外への移動世帯数がと もに一定值に達した時、1年が経過し、それに伴い、世帯の年齢と居 住年数が 1 増加し、年収が増減率に従い変化する。この一定值とは、 国勢調查（2000年）から得られた過去5年間の徳島県内間の移動世帯 数、県外一の移動世帯数を、 1 年毎の值に変換したものである。1年 が経過すると同時に、対象空間外からの移入や、出生、死亡といっ た自然増減によっても世帯数は変化する。

対象空間外から移入してくる世帯については、まず、ランダムに1 つのメッシュを選択し、その魅力度が対象地域内に存在するメッ シュの魅力度の平均值よりも高ければ、そこに移入する。そうでな ければ、再びランダムに別のメッシュを探索するが、対象地域内の 全メッシュ数以上の回数を繰り返しても条件を満たす場所が見つか らない場合は、最も魅力度が高いメッシュに移入する。対象地域外 から移入してくる世帯は、収入や周辺環境など各世帯の条件の違い から、その全てが最も魅力度の高いメッシュに移入するとは限らな い。そのため、移入先の選択では、魅力度の高いメッシュが優先さ れるものの、ある程度の不確定要素も含まれると考え、最初はラン ダムに選択している。

自然増により増加する世帯の出現位置は、対象空間外から移入し てくる場合と同じ手法を用いる。自然減については、65歳以上の高 齢世帯に対して年齢階級別死亡率より、生死の判断を行う。もし、 ある高齢世帯が次の年に死亡すると判断された場合、現実には、そ の世帯人員構成により次の3ケースが考えられる。高齢世帯が(1)高齢 単身世帯であれば世帯が消滅、(2)高齢夫婦世帯であれば配偶者が世 帯主となる、(3)高齢者以外の家族がいる場合はその中の最年長者が 世帯主となる。(2)と(3)の場合は、次の年でも世帯は残る。なお、本 モデルでは世帯の属性に世帯人員が含まれていないため、どのケー スに該当するかはランダムに判断することにした。

\section{6 相互作用}

2.1でも示したように、本モデルでは、世帯、地価、土地利用が互 いに相互作用を及ぼし合いながら変化する。ここでは、地価と土地 利用の変化について、その詳細を説明する。

地価については、メッシュ内で世帯が変化した際に、増加するか 減少寸るかを判別式により判別し、所与の変化量に応じて地価が変 化する。この判別式には乱数を用いた擋乱項が含まれている。

土地利用は、市街地から空地、農地から市街地、空地から市街地 への変化のみを想定する。その変化量については、市街地1[ha]あた りの平均世帯数を設定し、各メッシュの世帯数変化がその值に達し たとき、市街地比率が $1 \%$ 増加もしくは減少する。市街地が増加し、 メッシュ内に空地が存在する場合、空地比率が $1 \%$ 減少し、存在しな い場合、農地比率が $1 \%$ 減少する。空地と農地のどちらも存在しない 場合や市街地比率が既に $100 \%$ の場合、メッシュ内の市街地は増加し ない。逆に、市街地が減少すると、空地比率が $1 \%$ 増加する。 


\section{7 世帯属性の初期值とモデルのパラメータの設定}

次に世帯属性の初期值を設定寸る。

年齢、居住年数については、ランダムにメッシュに振り分けた が、対象地域全体での割合は、国勢調査（2000年）から得られる徳 島県全域の割合に従っている。年収もランダムにメッシュに振り分 けたが、こちらも対象地域全体での割合は、全国消費実態調査 （2004年）から得られる徳島県全域の年齢階級別平均年収の割合に 従っている。延べ面積と敷地面積は、住宅・土地統計調查（2003 年）を用いて年収別の居住室面積を集計し、世帯の年収に応じて与 えた。居住志向パターンはランダムに与えた。

式(1)の年齢に対する移動ポテンシャル $P^{a}{ }_{i}$ は、国勢調查の年齢階級 別移動割合を用いた。年収と居住年数に対する移動ポテンシャル $P_{i}^{r}$ と $P_{i}^{y}$ は、対象地域である徳島県のデータが存在しなかったため、 $P^{r}$ は尼崎市 ${ }^{12)}$ で、 $P^{y}{ }_{i}$ は大阪市 ${ }^{13)}$ で集計されていた類似のデータを利用し た。尼崎市や大阪市といった大都市と、対象地域のような地方都市 では移動の傾向が異なることが考えられるが、今回はデータの制約 上、両都市のデータを用いた。今後はアンケート調查などで対象地 域のデータを収集し、モデルで用いる必要がある。

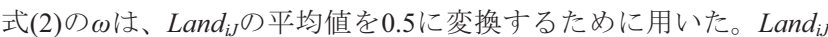
は、0〜1までの值となるように指数関数型で定式化したが、 $S_{i j}$ が $P^{a}{ }_{i 、} P^{r}{ }_{i 、} P^{y}{ }_{i}$ に比べて小さな值に偏ってしまったため、このような処 理を行った。具体的には、式(2)のS $S_{i J}$ をシミュレーション開始時の全 世帯の $S_{i J}$ の平均值、Land $i J$ を 0.5 として、式(2)より $\omega$ を計算し、 $\omega=15$ を得た。

式(3)の $\alpha_{1} \sim \alpha_{17}$ は、各居住パターンの特徴に従い、表4のように設定 した。 $\alpha_{3}$ と $\alpha_{6}$ は年齢が高いほど、 $\alpha_{11}$ は年収が低いほど高く設定して いる。 $\alpha_{4}$ は教育を受ける子供がいる世帯の多い30代前半で最大值 1 と なるように設定した。

式(4)の係数 $\beta_{1} \sim \beta_{6}$ と $\beta_{0}$ は、距離帯別に1990年から2000年までの世帯 数変化を集計し、多項式近似して求めた。式(5)で用いる犯罪発生 率、事故発生率、火災発生率は、各市町単位の值を用いた。式(7)の 係数 $\varepsilon_{1} \sim \varepsilon_{7}$ は、土地利用規制が新規開発に及ぼす影響から判断して $\varepsilon_{1}=1.0 、 \varepsilon_{2}=0.7 、 \varepsilon_{3}=0.5 、 \varepsilon_{4}=0.4 、 \varepsilon_{5}=0.4 、 \varepsilon_{6}=1.0 、 \varepsilon_{7}=1.0$ とした。

式(9)で用いる単位面積当たりの建築工事費Cost は、個人住宅規模 規格等調查（2004年）より $150,118\left[\right.$ 円 $\left./ \mathrm{m}^{2}\right]$ とした。課税標準額の割引 率 $\gamma_{1}$ と $\gamma_{2}$ は、土地の場合、地価の約 $70 \%$ 、建物の場合、建築費の約 50 〜 70\%とされている ${ }^{14)}$ ことから $\gamma_{1}=0.7 、 \gamma_{2}=0.6$ とした。固定資産税率と 都市計画税率は、各市町の值を用いる。地価の増減を判別する判別 式は、1990年から2000年の間に地価が増加、減少したメッシュに対 して判別分析を行った結果（判別率76.5\%）を用いた。判別式で用い た変数は、前年の移動世帯数、駅までの距離、県庁までの距離、森 林比率、市街化区域面積比率であり、判別式には乱数項も用いてい る。次に、地価の変化量は、対象地域の中心部と郊外部で異なるこ とが考えられるため、都市圈中心部（徳島駅から半径 $3[\mathrm{~km}]$ ）、市部 中心部（鳴門駅、南小松島駅から半径 $2[\mathrm{~km}]$ ）、それ以外の3地域に 分類し、各地域の、1世帯当たりの変化量の平均値を用いた。

式(14)の係数 $\eta_{1} \sim \eta_{3}$ は、現況土地利用が新規開発に及ぼす影響から 判断して $\eta_{1}=1.0 、 \eta_{2}=0.2 、 \eta_{3}=0.4$ とした。土地利用比率の計算で用い る市街地 $1[\mathrm{ha}$ ]当たりの平均世帯数は、人口集中地区（DID）と、そ の他の地区に分けて過去のデータから算出した。
最後に、自然減の判定で用いる年齢階級別死亡率は、人口動態統 計（2000年）を用いた。

\section{8 再現性の検討}

次に本モデルを用いて、居住志向パターン別に、式(7)の $\varphi_{1} \sim \varphi_{7}$ を 4 種類設定（表5）し、1990年から2000年までの世帯分布の再現を行 い最適な組み合わせを求めた。シミュレーション結果について は、誤差世帯総数、世帯数の平均誤差率、世帯数の相関係数、半径 次元の誤差率を計算し、再現性の指標とした。これらを表6に示寸。 誤差世帯総数とは、1990年から2000年までに変化した実際の世帯数 (観測值) とモデルで予測した世帯数（予測值）との差（誤差世帯 数）をメッシュ毎に求め、それらの值を総和したもの、世帯数の平 均誤差率とは、各メッシュの誤差世帯数の割合の平均值、世帯数の 相関係数は、観測值と予測值の相関係数である。半径次元 $D$ とは、フ ラクタル次元の一種で、分布の形態的な特徴をみるために用いた指 標である。渡辺ら ${ }^{15}$ は、この指標を用いて市街地分布形態の類似度 を比較しているが、ここでは、世帯の空間分布の類似度を比較す る。計算方法は、世帯数の重心を求め、そこから半径 $r$ を $1[\mathrm{~km}]$ ずつ 増やした円を描き、その円内に含まれる世帯数 $N$ を数えて式(15)より 算出する。

$N=r^{D}$

表4 居住志向パターンのパラメータ

\begin{tabular}{|c|c|c|c|c|c|c|c|c|}
\hline 居住志向パターン & $\alpha_{1}$ & $\alpha_{2}$ & $\alpha_{3}$ & $\alpha_{4}$ & $\alpha_{5}$ & $\alpha_{6}$ & $\alpha_{7}$ & $\alpha_{8}$ \\
\hline 中心市街地型 & 1 & 1 & 変化 & 変化 & 0.5 & 変化 & 1 & 1 \\
\hline 郊外部型 & 0.5 & 0.5 & 変化 & 変化 & 1 & 変化 & 1 & 1 \\
\hline コミュニ1重視型 & 0.6 & 0.6 & 変化 & 変化 & 1 & 変化 & 1 & 1 \\
\hline 経济性重視型 & 0.5 & 0.5 & 変化 & 変化 & 0.5 & 変化 & 1 & 1 \\
\hline 無関心型 & 乱数 & 乱数 & 乱数 & 乱数 & 乱数 & 乱数 & 乱数 & 乱数 \\
\hline 居住志向パターン & $\alpha_{9}$ & $\alpha_{10}$ & $\alpha_{11}$ & $\alpha_{12}$ & $\alpha_{13}$ & $\alpha_{14}$ & $\alpha_{15}$ & $\alpha_{16}$ \\
\hline 中心市街地型 & 1 & 変化 & 0.5 & 0.5 & 0.5 & 1 & 0.2 & 0.5 \\
\hline 郊外部型 & 1 & 変化 & 1 & 0.5 & 1 & 1 & 1 & 1 \\
\hline コミニニイ重視型 & 1 & 変化 & 0.5 & 0.5 & 1 & 1 & 1 & 1 \\
\hline 経済性重視型 & 1 & 1 & 0.5 & 1 & 0.5 & 1 & 0.5 & 0.5 \\
\hline 無関心型 & 乱数 & 乱数 & 乱数 & 乱数 & 乱数 & 乱数 & 乱数 & 乱数 \\
\hline
\end{tabular}

変化: 年齢や年収に応じて変化する/乱数: 全くランダムに数值を与える

表5＼cjkstart居住志向パターン別の $\phi$

\begin{tabular}{|c|c|c|c|c|c|c|c|c|}
\hline No & 居住志向パターン & $\varphi_{1}$ & $\varphi_{2}$ & $\varphi_{3}$ & $\varphi_{4}$ & $\varphi_{5}$ & $\varphi_{6}$ & $\varphi_{7}$ \\
\hline \multirow{5}{*}{1} & 中心市街地型 & 1.0 & 1.0 & 1.0 & 1.0 & 1.0 & 1.0 & 1.0 \\
\hline & 郊外部型 & 1.0 & 1.0 & 1.0 & 1.0 & 1.0 & 1.0 & 1.0 \\
\hline & コミユニティ重視型 & 1.0 & 1.0 & 1.0 & 1.0 & 1.0 & 1.0 & 1.0 \\
\hline & 経済性重視型 & 1.0 & 1.0 & 1.0 & 1.0 & 1.0 & 1.0 & 1.0 \\
\hline & 無関心型 & ランダム & ランダム & ランダム & ランダム & ランダム & ランダム & ランダム \\
\hline \multirow{5}{*}{2} & 中心市街地型 & 1.0 & 1.0 & 1.0 & 1.0 & 0.3 & 0.3 & 0.3 \\
\hline & 郊外部型 & 0.5 & 0.3 & 0.3 & 0.3 & 1.0 & 1.0 & 0.5 \\
\hline & コミユニティ重視型 & 1.0 & 0.3 & 0.3 & 0.3 & 0.5 & 0.5 & 0.5 \\
\hline & 経済性重視型 & 0.3 & 0.3 & 0.3 & 0.3 & 1.0 & 1.0 & 1.0 \\
\hline & 無関心型 & ランダム & ランダム & ランダム & ランダム & ランダム & ランダム & ランダム \\
\hline \multirow{5}{*}{3} & 中心市街地型 & 1.0 & 1.0 & 0.5 & 0.5 & 0.3 & 0.3 & 0.1 \\
\hline & 郊外部型 & 0.5 & 0.3 & 0.3 & 0.3 & 1.0 & 1.0 & 0.8 \\
\hline & コミユニティ重視型 & 1.0 & 0.3 & 0.3 & 0.3 & 0.8 & 0.8 & 0.5 \\
\hline & 経済性重視型 & 0.5 & 0.3 & 0.3 & 0.3 & 1.0 & 1.0 & 1.0 \\
\hline & 無関心型 & ランダム & ランダム & ランダム & ランダム & ランダム & ランダム & ランダム \\
\hline \multirow{5}{*}{4} & 中心市街地型 & 0.8 & 1.0 & 0.3 & 0.3 & 0.3 & 0.6 & 0.3 \\
\hline & 郊外部型 & 1.0 & 0.5 & 0.3 & 0.3 & 0.8 & 1.0 & 0.3 \\
\hline & コミユニティ重視型 & 0.7 & 0.5 & 0.3 & 0.3 & 0.7 & 0.7 & 0.3 \\
\hline & 経済性重視型 & 0.5 & 0.5 & 0.5 & 0.3 & 0.5 & 0.5 & 0.5 \\
\hline & 無関心型 & ランダム & ランダム & ランダム & ランダム & ランダム & ランダム & ランダム \\
\hline
\end{tabular}

表6 再現性の検討

\begin{tabular}{|c|r|r|r|r|r|r|}
\hline \multirow{3}{*}{ No } & \multicolumn{3}{|c|}{ 世帯数 } & \multicolumn{3}{|c|}{ 半径次元 } \\
\cline { 2 - 7 } & 誤差総数 & 平均誤 & 相闦 & \multicolumn{3}{|c|}{ 誤羞 $[\%]$} \\
\hline 1 & & 率 & 係数 & $0-5[\mathrm{~km}]$ & $5-14[\mathrm{~km}]$ & $14-20[\mathrm{~km}]$ \\
\hline 2 & 44,431 & 0.36 & 0.97 & -1.0 & 3.0 & 40.4 \\
\hline 3 & 40,108 & 0.35 & 0.97 & 2.6 & -1.2 & 26.7 \\
\hline 4 & 41,414 & 0.33 & 0.97 & 4.2 & -0.3 & 29.6 \\
\hline 4 & 46,704 & 0.34 & 0.96 & -1.2 & 2.8 & 38.0 \\
\hline
\end{tabular}


$D$ は、都市圈中心部、郊外部、郊外部周辺地域で異なる傾向を示し ていたことから、重心からの距離を $5[\mathrm{~km}]$ 以下、5～14[km]、14[km] 以上の3つに分けて算出し、観測值と予測值の誤差率を求めた。

表6より、各指標とも大きな違いはみられなかったものの、No2 と No3の組み合わせが他よりも精度が高くなった。本モデルでは世帯数 を予測することから、平均誤差率が最も小さかったNo3の組み合わせ を採用した。

\section{LUPSの開発}

\section{1 システムの概要}

前章で開発したHDPMとGISソフトを用いてLUPSを開発する。利 用するGISソフトは、SIS6.2（インフォマティクス）である。SISで は、用いるデータ管理やシミュレーション結果の表示等を行う。 HDPMは、Artisoc1.0（構造計画研究所）を用いて開発し、操作パネ ルなどを付加させるためにVisual Basic2005を介してSISに組み込む。

\section{2 システムの機能}

ここでは、システムの機能について説明する。以下に挙げた機能 は、筆者らが土地利用計画に関わっている実務者に対して行ったア ンケート調查結果 ${ }^{16)}$ を基に選択したものである。

\section{(1) 世帯の空間分布予測機能}

これは、HDPMを用いて、ユーザーが想定した計画案に含まれる 土地利用規制や税率等が実施された場合に変化する世帯の空間分布 を予測することで、計画案の評価情報を提供する機能である。

\section{(2) 情報表示機能}

システム内で管理している情報をユーザーが自由に検索、閲覧で きる機能である。計画案の作成や検討時に、整備したデータを参考 情報として表示させることで、作業の効率化を目指すものである。

\section{(3) 情報更新機能}

これは、HDPMや現況把握で用いるデータを、システム上で更新 する機能である。メッシュ形式やベクタ形式のデータも、直接LUPS 上で更新することで、それと同時に距離や面積計測を行い、HDPM で利用できる形式に変換する。

\section{(4) 地図出力機能}

これは、HDPMの予測結果など必要なデータを地図形式で出力す る機能である。

\section{(5) フレーム值推計機能}

これは、土地利用計画図の作成や用途地域の指定の際に行う、フ レーム值や各種土地利用地域の面積推計を行う機能である。LUPSで は、アンケート調查結果 ${ }^{16)}$ で示されていた実務で多く利用されてい る手法 ${ }^{17)}$ を用いて、次式により工業用地面積 $A r e a_{\text {ind }}[\mathrm{ha}]$ 、商業用地面 積Area ${ }_{\text {comm }}[\mathrm{ha}] 、$ 住宅用地面積 $A r e a_{\text {resi }}[$ ha] 算出する。

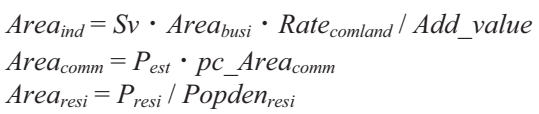
Area $_{\text {resi }}=P_{\text {resi }} /$ Popden $_{\text {resi }}$

ここで、Svは工業出荷額 [ 円]、Area busi は事業所敷地面積 [ha] Rate $_{\text {comland }}$ は公共用地比、Add_valueは付加価值額 $\left[\right.$ 円]、 $P_{\text {est }}$ は推計人 口、pc_Area $a_{c o m m}$ は人口一人あたりの商業用地面積[ha]、 $P_{\text {resi }}$ は住宅用 地内人口、Popden resi $_{\text {は }}$ は住宅用地人口密度 $[$ 人/ha]である。
ユーザーはこれらの数值を独自に設定することが可能であるが、 起動時はデフォルト值が入るようになっている。各デフォルト值は 次のとおりである。Sv、Area busi、Add_valueは過去15年間の工業統計

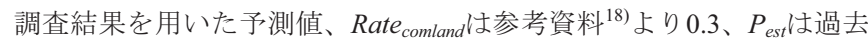
5 時点の国勢調查結果を用いた予測值、pc_Area $a_{\text {comm }}$ は参考資料 ${ }^{18)}$ より $10\left[\mathrm{~m}^{2}\right] 、 P o p d e n_{\text {resi }}$ は参考資料 ${ }^{19)}$ より $80[$ 人 $/ \mathrm{ha}]$ とした。P resi は次式で計 算する。

$P_{\text {resi }}=P_{\text {est }}-$ Area $_{\text {ind }} \cdot$ Popden $_{\text {ind }}-$ Area $_{\text {comm }} \cdot$ Popden $_{\text {comm }}$

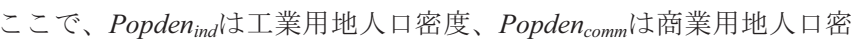

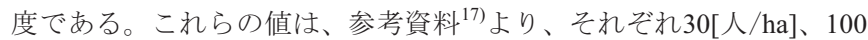
[人/ha]をデフォルト值とした。 システムの画面を図2に示す。

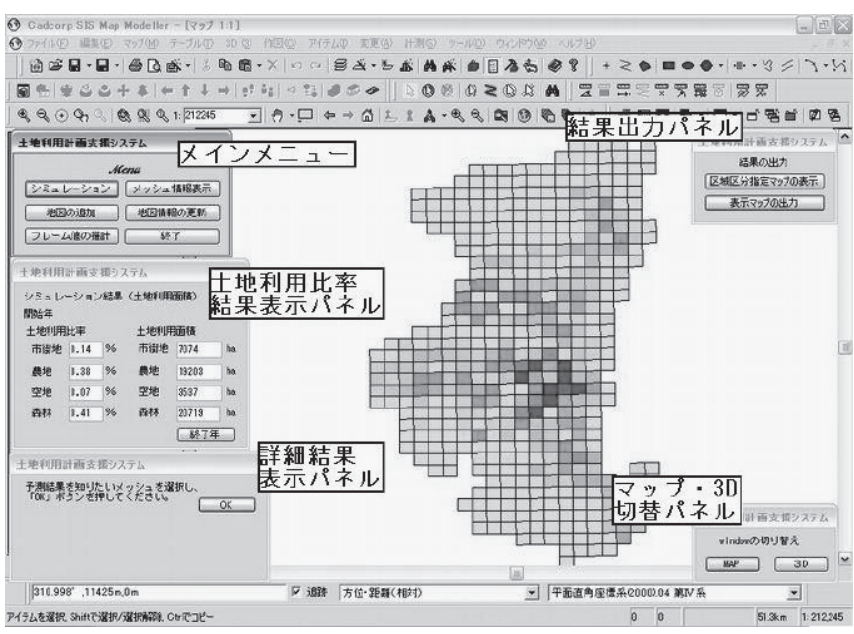

図2 システムの画面構成

\section{LUPSの適用}

\section{1 想定したシナリオ}

本章では、LUPSを研究対象地域に適用し、その妥当性を検証す る。ここでは、区域区分の変更に伴う世帯分布の変化をみるため に、区域区分以外の指標はデフォルト值を用い、以下の3つのシナリ オの基で、2000年を初期值とする2010年の世帯数予測を行った。

シナリオ $1:$ 現在の区域区分を変更しない

シナリオ 2 : 徳島市の市街化区域のみ残し、他を全て市街化調整区 域にする

シナリオ 3 : 研究対象地域全域で区域区分を廃止する

図3に対象地域の区域区分を、図4に2000年の世帯分布、図5に2010 年の予測結果 (2000年から変化した世帯数) を示す。図3より、研究 対象地域には、藍住町のみの藍住都市計画区域と、それ以外の徳島 東部都市計画区域が存在する。前者は区域区分が指定されていな い、いわゆる未線引き区域であり、後者は市街化区域と市街化調整 区域（調整区域）が指定されている都市計画区域である。なお、鳴 門市には北部に一部都市計画区域外も含まれている。藍住町は、都 市計画区域指定当初より未線引きであり、かつ農地を中心とする平 坦な地形であることから、沿道開発が盛んで、近年は大規模商業施 設の進出も相次いでいる。また、徳島市や鳴門市のベットタウンと して住宅地開発も進んでおり、表1に示寸ように人口も増加傾向にあ 
る。一方、徳島、鳴門、小松島といった市部では、中心部を始め人 口減少が著しい。

このような中、シナリオ1では、現状の土地利用規制が変更されな かった場合、将来、どのような世帯分布となるのかを予測する。シ ナリオ2は、都市圈の中心都市である徳島市の夕現状の市街化区域を 残し、他は全て調整区域とすることで、これまで主に藍住町に向 かっていた開発圧力が市街化区域に向かい、結果としてコンパクト な市街地形成（コンパクトシティ）を実現できるのではないかと考 えたシナリオである。シナリオ 3 について、徳島東部都市計画区域 の整備、開発及び保全の方針（平成16年） ${ }^{20)}$ では、区域区分廃止に 否定的な方針が述べられていることから、現実的には実施される可 能性は低いものの、区域区分の効果を評価するために重要な条件と 考え、想定シナリオに含めることにした。

\section{2 予測結果}

図 5 より、シナリオ 1 の結果を見ると、未線引き区域である藍住町 のほぼ全域で世帯数が増加する一方、徳島市中心部では減少が予測 された。このことより、現状では、規制の緩い藍住町で市街化が進 行し、徳島市の中心市街地では世帯減少が続くことがわかった。

シナリオ 2 結果を見ると、徳島市以外を全て調整区域にするとい う強い開発規制を加えたため、藍住町を除く全ての市町の中心部で

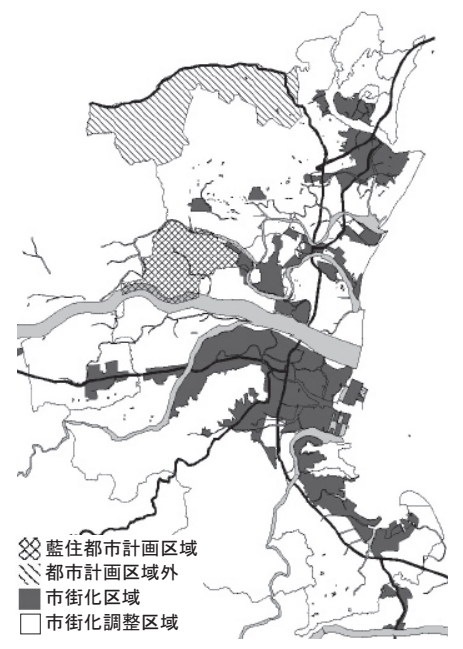

図3 区域区分指定状況

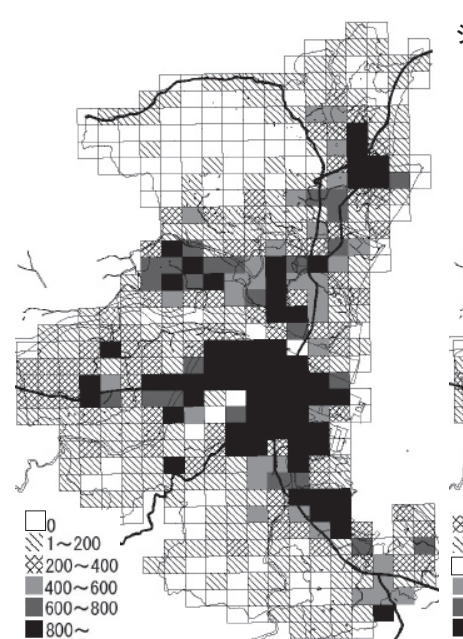

図4 世帯数（2000年） $400 \sim$

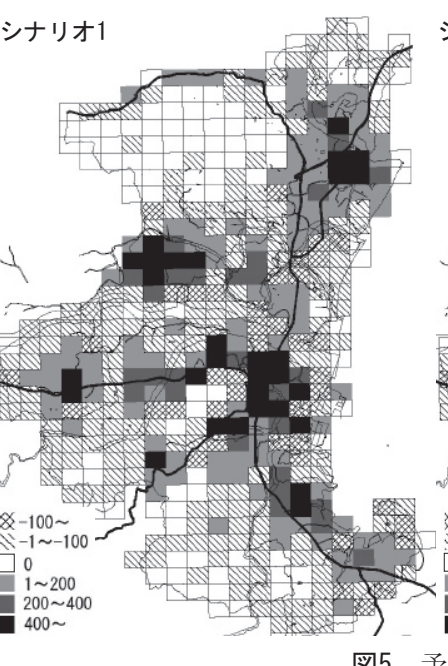

図5
世帯増加がみられた。しかし、シナリオ1と比較すると、その増加量 は少なくなっており、徳島市の中心部での増加量が多くなってい る。これは、徳島市以外の地域では、開発規制による土地の魅力度 が減少し、そうした地域に在住する世帯の中でも、特に中心市街地 志向型の世帯が徳島市中心部へと集まってきたと考えられる。この 結果より、シナリオ 2 は中心市街地活性化につながる可能性があると 考えられる。

シナリオ3の結果を見ると、全域で区域区分を廃止したことによ り、藍住町での世帯増加が抑制され、都市部の中心や国道沿いで世 帯増加がみられた。これは、土地利用規制による影響がなくなった ことで、利便性の高い場所一の世帯移動が多くなったためと考えら れる。また、この結果から現在の藍住町での世帯増加は、土地利用 規制による影響が強い、つまり、藍住町のみが規制の緩い未線引き 区域であるために起こっていると考えられる。

以上、LUPSを用いて、区域区分に関する3つのシナリオが実施さ れた場合の世帯数変化予測を行った。その結果、区域区分の指定が 世帯分布に及ぼす影響を把握することができた。

\section{5. 結論}

本研究では、MASを用いて世帯の移動行動をモデル化し、3次メッ シュ単位で分布を予測するHDPMを開発した。このモデルをGISソフ トに組み込み、土地利用計画に関する機能を付加させた、LUPSを開 発した。これを用いて、区域区分指定に関する3つのシナリオを想定 し、その効果を世帯分布で予測した。その結果、現状の区域区分指 定のままでは、今後も藍住町を中心とする郊外化と徳島市中心部の 空洞化が続くこと、徳島市のみに市街化区域を残し、他を全て調整 区域に指定した場合は、郊外化が抑制され中心市街地活性化につな がる可能性があること、そして、全域で区域区分を廃止した場合 は、藍住町での世帯増加が抑制され、都市部の中心や国道沿いで世 帯増加が起こる可能性があることがわかった。

今後の課題を以下に示す。

(1)HDPMでは、MASを用いて世帯の移動行動をモデル化したが、ラ ンダムに選んだメッシュの魅力度と現状の魅力度とを比較し、そ れのみにより移動を決定している。現実の居住地選択行動では、 世帯は複数の居住地候補を比較検討しながら移動先を決定するこ とが考えられるが、この部分がモデル化できていない。今後は、

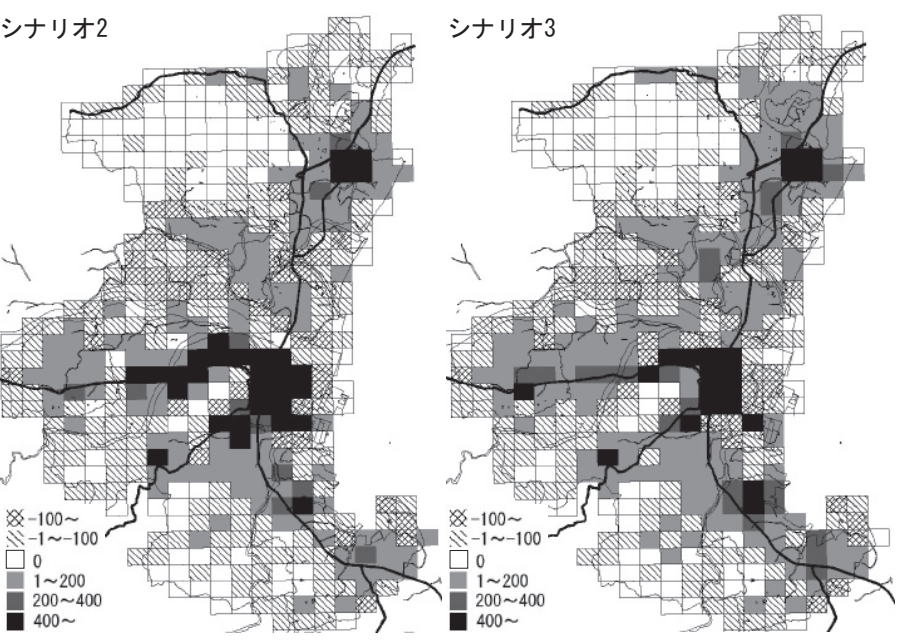

予測結果（2000～2010年までの変化世帯数） 
複数の候補地を同時に比較するプロセスもモデルに組み込む必要 がある。

(2)土地の魅力度には多くの変数が含まれることから、パラメータ設 定が困難である。実務への応用を考えると、今後は変数を取捨選 択し、できるだけ少ない変数で予測が可能なモデルに改良する必 要がある。

(3)世帯属性に世帯人員が含まれていないため、世帯分離や世帯消滅 などを正確にモデル化できなかった。今後は、世帯人員の変化を モデルに組み込む必要がある。

(4)LUPSでは、区域区分や用途地域指定・変更による世帯分布を予測 することが可能である。しかし、現実の土地利用計画では、世帯 分布以外にも人口や交通量など他の指標で、土地利用計画の評価 を行いたい場合も考えられることから、これらの予測モデルとの 統合も課題である。

\section{付記}

本研究は科学研究費補助金（若手研究B、2006～2007年度、No. 18760463）による成果の一部である。

\section{参考文献}

1）奥 俊信 : 土地利用間の親和度に基づく土地分凝形態の特徴一マルチエー ジェントの満足度戦略による土地移転モデルー、日本建築学会環境系論文 集、No.588、pp.71-77、2005.2

2) 奥 俊信 : 用途地域制度に基づいた土地利用用途間の親和度設定による土地 利用形態一マルチェージェントの満足度戦略による土地移転モデルその 2-、日本建築学会環境系論文集、No.605、pp.147-154、2006.7

3) 奥 俊信 : 主に空地を介した土地利用移転によって形成される土地利用パ ターンの特徴ーマルチェージェントの満足度戦略による土地移転モデルそ の3一、日本建築学会環境系論文集、No.617、pp.87-94、2007.7

4) Masanobu Kii, Kenji Doi: Multi agent land-use and transport model for the policy evaluation of a compact city, Environment and Planning B: Planning and Design, Vol.32, pp.485-504, 2005

5) 池谷直樹、谷本 潤、荻島 理、相良博喜：マルチェージェント・シミュ レーションに基づく都心部における人口分布の過渡的動態モデルに関する 研究、日本建築学会技術報告集、Vol.13、No.26、pp.845-848、2007.12

6) 安藤陽介、横田敬司、吉川徹 : 都市衰退過程での空き家の発生と集積およ び空地の商業への影響に着目したマルチェージェントシステムによる都市 シミュレーション、都市計画論文集、No.40-1、pp.51-59、2005.4

7) 呉 愚如、荻島 哲、大貝 彰、鵤 心治：メッシュデータによる新用途地域 指定における支援エキスパートシステムの開発に関する研究、日本建築学 会計画系論文集、No.512、pp.191-198、1998.10

8) 大貝 彰、渡辺公次郎、五十嵐 誠：パーソナルコンピュータ上で稼働する GISを用いた土地利用計画立案支援ツールの試験的開発、日本都市計画学 会学術研究論文集、No.34、pp.751-756、1999.11

9) 長崎浩紀、渡辺公次郎、大貝 彰、ディビガルピティアプラサンナ、近藤 光男：開発途上国における土地利用計画支援ツールの開発、GIS 一理論と 応用、Vol.14、No.2、pp.157-168、2006.12

10) 金 俊栄、萩島 哲、大貝 彰、岩尾 襄、黒瀬重幸：土地利用遷移行列によ る都市の土地利用用途転換の分析、日本建築学会計画系論文報告集、 No.424、pp.69-78、1991.6

11) 葛 堅、外尾一則：居住性志向を考慮した居住ライフスタイルに関する研 究、土木計画学研究・講演集、Vol.29、pp.136-143、2004.6

12) 尼崎市: 平成 18 年度人口等都市政策調査研究事業報告書、 2006.3

13) 大阪市: 第5回大阪市人口移動要因調查、2005.9

14) 東京都主税局：「固定資産税・都市計画税」、（オンライン）、入手先 $<$ http://www.tax.metro.tokyo.jp/shisan/kotei_tosi.html> 、参照2007.12

15) 渡辺公次郎、大貝 彰、五十嵐 誠：セルラーオートマタを用いた市街地形
態変化のモデル開発、日本建築学会計画系論文集、No.533、pp.105-112、 2000.7

16) 長崎浩紀、渡辺公次郎、近藤光男：GISを用いた土地利用計画支援ツール に関するアンケート調査、日本建築学会技術報告集、Vol.26、pp.795-800、 2007.12

17) 福島県 : 都市計画決定の手引、2002

18) 加藤 晃、河上省吾 : 都市計画概論 [第2版]、共立出版株式会社、1990.10

19) 国土交通省 : 都市計画運用指針、2006.11

20) 徳島県 : 徳島東部都市計画区域の整備、開発及び保全の方針、2004.3

（2008年 5 月 8 日原稿受理，2008年11月 5 日採用決定） 